\title{
Duplicity of caudal vena cava and renal veins in a Brazilian shorthaired cat - a case report
}

\author{
Anieli Vidal Stocco ${ }^{1}$, Carlos Augusto dos Santos-Sousa ${ }^{2,3}$, Paulo Souza- \\ Junior $^{4}$, Karen Toledo ${ }^{1,2}$, and Marcelo Abidu-Figueiredo ${ }^{1 *}$ \\ ${ }^{1}$ Department of Animal and Human Anatomy, Biology and Health Sciences Institute, Federal Rural University \\ of Rio de Janeiro, Rio de Janeiro, Brazil \\ ${ }^{2}$ Postgraduate Program in Animal Biology, Federal Rural University of Rio de Janeiro, Rio de Janeiro, Brazil \\ ${ }^{3}$ Center for Biological and Nature Sciences, Federal University of Acre, Brazil \\ ${ }^{4}$ Department of Veterinary Medicine, Federal University of Pampa, Brazil
}

STOCCO, A. V., C. A. DOS SANTOS-SOUSA, P. SOUZA-JUNIOR, K. TOLEDO, M. ABIDU-FIGUEIREDO: Duplicity of caudal vena cava and renal veins in a Brazilian shorthaired cat - a case report. Vet. arhiv 89, 257-265, 2019.

ABSTRACT

The caudal vena cava in carnivores is the blood drainage pathway, originating from the pelvis and pelvic limbs, and entering the right atrium. Caudal vena cava duplication has rarely been reported in small animals. This report aims to describe a case of duplicity of the caudal vena cava and renal vein variation in a female feline corpse of a Brazilian shorthaired cat approximately 3 years of age, with the focus on the possible clinical and surgical implications of this anatomical variation. It was subsequently preserved in $10 \%$ formalin, and its vascular system was injected with colored S-65 Petrolatex. During the dissection of the abdominal region, the presence of a double caudal vena cava and two renal veins in both kidneys was observed. While uncommon in cats, caudal vena cava duplication should be differentiated from other vascular anomalies when planning surgeries and to avoid misdiagnoses.

Key words: Brazilian shorthaired cat; abdominal vessels; anatomic variation

\section{Introduction}

In mammals, the caudal vena cava (CVC) develops as a composite structure via the chronological events of formation, regression, anastomosis, and substitution of three symmetrical sequential pairs of veins: the supracardinal, subcardinal, and navel veins (BUTLER, 1927; SCHWARZ et al., 2009; ŠEHIĆ, 2017)

\footnotetext{
${ }^{*}$ Corresponding author:

Marcelo Abidu Figueiredo, Department of Animal and Human Anatomy, Biology and Health Sciences Institute, Federal Rural University of Rio de Janeiro, BR 465, Km 07, s/n - Zona Rural, Seropédica, Rio de Janeiro, Brazil, 23890-000, Phone +55 21 2682 1080; E-mail: marceloabidu@gmail.com
} 
The CVC opens into the caudal part of the sinus venosus of the right atrium. It runs into the plica venae cavae through the right pleural cavity to the foramen venae cavae in the tendinous center of the diaphragm. As it enters the abdominal cavity, it turns dorsal between the right crus and the liver. At this point, it creates an impression, the sulcus venae cavae, on the diaphragmatic surface of the liver, which varies in depth among species and individuals. It passes over the dorsal border of the liver, at first still applied to the diaphragmatic crus, to reach a location ventral to the vertebral column and to the right of the abdominal aorta (KÖNIG and LIEBICH, 2016).

In humans, the prevalence of duplication of the inferior vena cava (IVC) has been reported in $0.2 \%-3 \%$ of the individuals studied (BASS et al., 2000). Duplication and other anomalies of this vessel may be associated with a higher risk of deep venin thrombosis (SARLON et al., 2011). In most cases, duplication of the IVC is clinically silent, identified only during imaging studies, surgeries, or necropsies (ITO and IKEDA, 2018).

The right IVC is typically reassembled through four caudocranial embryologic segments: subrenal, renal, suprarenal, and hepatic. The posterior cardinal veins persist as the caudal portion of the subrenal segment that produces the common iliac veins and the bifurcation. The supracardinal vein produces the cranial portion of the subrenal segment. The right subcardinal-supracardinal anastomosis produces the renal segment. The subcardinal vein provides the supra-renal segment. The cardiohepatic canal produces the hepatic segment (ARTICO et al., 2004). Each pair of veins is identical in origin but not in position, and the unusual development of these venous systems, for unknown reasons, causes variations in the IVC and alters the venous map of the abdomen (ARTICO et al., 2004). Its pathogenesis is generally attributed to the failure of regression of the left supracardinal vein (MAO et al., 2015).

Duplication of the CVC has rarely been reported in domestic animals. In the reported cases, the anomaly has been primarily described as an incidental finding during imaging for other reasons, and has been associated with other congenital anomalies (HUNT et al.,1998; BERTOLINI, 2010).

This communication aims to report a case of duplicity of the CVC, associated with duplication of the right and left renal veins in a cat, with the focus on the possible clinical and surgical implications of this anatomical variation.

\section{Materials and methods}

The research ethics committee of Rio de Janeiro Federal Rural University approved this study (23083.005334/2009-49).

During dissection activities performed in the Animal Anatomy Laboratory of the Animal and Human Anatomy Department of the Federal Rural University of Rio de Janeiro, a numerical variation was observed in the CVC and the left renal vein of a female Brazilian shorthaired cat, approximately 3 years old. This cadaver was previously 
identified and positioned in right lateral recumbency. By a thoracic incision, his sixth and seventh ribs were removed. His thoracic aorta was dissected, cannulated to wash the vascular system with saline solution, and fixed with a $10 \%$ formaldehyde solution. Then, the vascular system was filled with colored stained Petrolatex S-65 solution (Refinaria Duque de Caxias-REDUC-Petrobras, Duque de Caxias-RJ) mixed with the dye Suvinilxadrez ${ }^{\circledR}$.

After this the cadaver was immersed in a low-density polyethylene cardboard box, with 500-L capacity, containing a 10\% formaldehyde solution, to finalize the fixation and latex polymerization processes. Seven days after injection of the latex, the cadaver was washed in running water, the peritoneal cavity was opened, and the structures were dissected.

\section{Results}

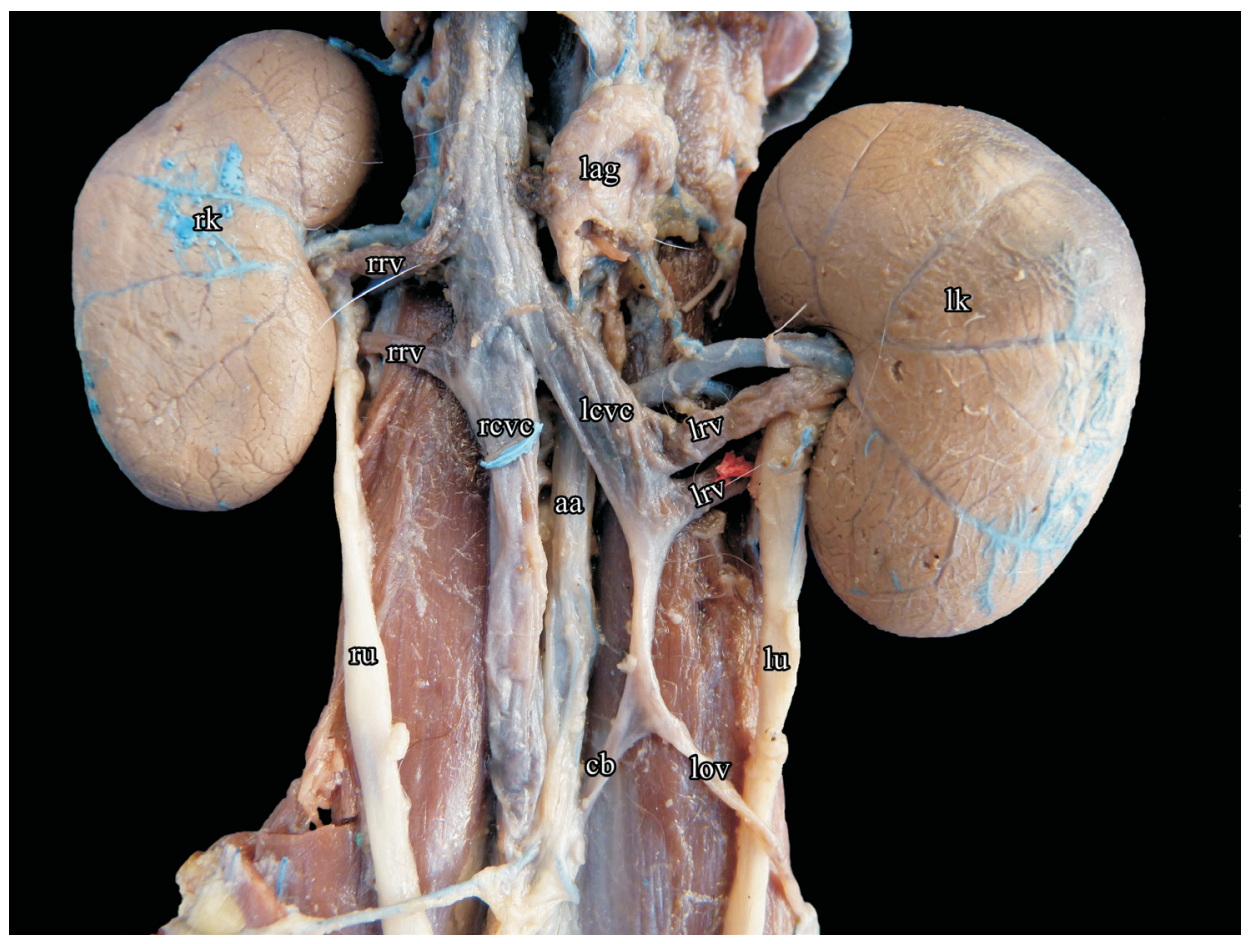

Fig. 1. Photomacrography showing the duplicity of the CVC and two renal veins in both kidneys: rk - right kidney, rrv - right renal vein, rcvc - right CVC, ru - right ureter, aa - aorta artery,

lag - left adrenal gland, lcve - left CVC, lrv - left renal vein, lu - left ureter, lov - left ovarian vein, lk - left kidney, cb - communicating branch 
In this case report, two bilaterally asymmetrical caudal venae cavae were observed, ascending along the right and the left sides of the abdominal aorta in this female cat; the left CVC joined the left renal veins to form a common trunk (preaortic trunk), which then crossed obliquely upwards from left to right ventrally to the aorta and joined the right CVC.

The cat in this investigation resembles a type 2a according to the CHEN et al. (2012) classification, and a type III complete duplication in accordance with NATSIS et al. (2010).

Also, two left and right renal veins were observed, one cranioventral and the other caudodorsal. The first left renal vein (cranioventral) measured $1.20 \mathrm{~cm}$ and the second (caudodorsal), $1.36 \mathrm{~cm}$. The first right renal vein (cranioventral) measured $1.31 \mathrm{~cm}$ and the second (caudodorsal), $1.35 \mathrm{~cm}$ (Fig. 1).

\section{Discussion}

Anatomical variations, including those in the position, diameter, and running course of double caudal venae cavae, are vary between cases. A double CVC is a standard arrangement in whales and dolphins and has been reported as an uncommon variant in humans (BASS et al., 2000) and domestic animals (REIS and TEPE, 1956; LABORDA et al., 1996; CACERES et al., 2008).

Embryogenesis of the IVC is a complex process involving the development, regression, anastomosis, and replacement of the three main embryonic veins (MATHEWS et al., 1999; BASS et al., 2000). In the sequence of presentation, these vessels are: the posterior cardinal, the subcardinal, and the supracardinal veins. The posterior cardinal veins appear first on the posterior aspect of the embryo. These veins regress, except for the distal aspects, which become the iliac bifurcation. The subcardinal veins then appear anterior and medial to the posterior cardinal veins. The right subcardinal vein remains to form the suprarenal IVC, while the left subcardinal vein completely regresses. Subsequently, the supracardinal veins appear dorsally to the subcardinal veins. The left supracardinal vein then regresses, and the right supracardinal vein forms the infrarenal IVC. The normal IVC is converted to a unilateral, right-sided system, consisting of four components:

(1) the infra-renal segment from the right supracardinal vein,

(2) the renal segment from the right supracardinal anastomosis,

(3) the supra-renal segment from the right subcardinal vein, and

(4) the hepatic segment from the right hepatic vein.

Thus, a double IVC is considered to be due to the persistence of both supracardinal veins (MATHEWS et al., 1999; BASS et al., 2000).

The complete duplication found in the cat reported here may be associated with either the prerenal or the left side of the renal segments of the CVC. The exact development of the inferior/CVC in humans and animals is an issue that has not yet been fully clarified, 


\section{A. V. Stocco et al.: Duplicity of caudal vena cava and renal veins in a feline}

and different developmental theories have been proposed (CORNILLIE and SIMOENS, 2005; CORNILLIE et al., 2008). The definitive abdominal CVC is typically a single right-sided vessel that develops in five segments: prerenal, renal, prehepatic, hepatic, and posthepatic (HUNT et al., 1998). This same type of duplication was observed by BERTOLINI (2010) in different breeds of dogs, although in the present report, there was no vessel symmetry.

Many classification systems have been proposed to improve the understanding of the different anomalies that may occur during the development of the IVC (McCLURE and BUTLER, 1925; MORITA et al., 2007). The most commonly used classification is based on the segment of the final vena cava that is abnormal. CHEN et al. (2012) proposed a simple classification of the IVC into three types: normal (right), double, and left IVC. In the case of the double IVC, this anomaly was further classified according to the pattern of the interiliac veins. An interiliac vein was defined as a vein that drained the blood from the common iliac veins into the contralateral side of the double IVC. Thus, variations of the IVC were classified as follows: type 1, normal iliac communication; type 2a, double IVC with no interiliac vein; type $2 b$, double IVC with interiliac vein from the left common iliac vein; type $2 \mathrm{c}$, double IVC with interiliac vein from the right common iliac vein; type $2 \mathrm{~d}$, interiliac vein connecting the double IVC, runs transversely; type 3 , left IVC with a symmetrical-to-normal iliac connection.

According to the human classification system proposed by CHEN et al. (2012), the cat in the present investigation resembles a type 2a. Following a previously published human classification system, the cat in the present study has a type III complete duplication, with the two vessels and the oblique venous trunk having approximately the same caliber (JOHNSTON, 1913; NATSIS et al., 2010).

In humans, in another aspect, two types of duplication of the IVC can be considered: complete and incomplete (XUE et al., 2006). A complete duplication is where, after receiving the left renal vein, the left IVC continues with a venous trunk anterior to the aorta (preaortic trunk); this represents a persistent intersubcardinal anastomosis, traveling obliquely, and emptying into the right IVC. The complete duplication is further subdivided into the following three types: type I, which comprises two bilaterally symmetrical cava veins and a preaortic trunk of the same caliber (due to the persistence of the two supracardinal veins and the intersubcardinal anastomosis); type II, which exhibits two bilaterally symmetrical trunks that are smaller than the preaortic trunk (persistence of the supracardinal veins and the failure to regress of the intersubcardinal anastomosis); and type III or asymmetric duplication, which comprises a smaller left IVC than the right one and a preaortic trunk (failure of regression of the left supracardinal vein). An incomplete pattern is defined when the left iliac vein ascends as a duplicated left IVC and drains into the left renal vein, which then travels anteriorly to the aorta and joins the right IVC in the normal fashion. 
Numerical variations of the renal arteries have been described in dogs (OLIVEIRA and GUIMARÃES, 2007; ALONSO and ABIDU-FIGUEIREDO, 2008), cats (PESTANA et al., 2011), and rabbits (ALMEIDA et al., 2013). These reported variations are more frequently observed in arteries than in veins, although CAMPOS et al. (2014) and STOCCO et al. (2014) reported double renal veins in both kidneys, and triplet veins in only the right kidney, in cats, respectively.

REIS and TEPE (1956) dissected the renal veins of 500 mongrel dogs (287 males and 213 females) and observed the presence of a double right renal vein in $1 \%(n=5)$ and a single left renal vein in all cases, in contrast to the results obtained by FAGUNDES et al. (1990), in which duplicity was only found in the right kidney. Vascular duplicity, when present, is usually observed in routine dissections or during imaging tests. According to XUE et al. (2006), duplication of the IVC and vascular variations of the kidneys are not only important from a developmental point of view but also have important clinical implications. These anomalies can manifest as various clinical symptoms and can affect the approach to surgical procedures. The presence of duplicate IVC poses hazards during abdominal aortic surgery. In addition to increasing the complexity of kidney transplantation, they increase the percentage of procedural failures.

STOCCO et al. (2017), in a report on a specimen of Leopardus pardalis, emphasized that any abdominal surgery that requires mobilization or hemostatic control of the renal vessels requires a systematic search for possible vascular anatomic variations. In this context, a renal transplant may be performed in a companion animal surgical clinic as a therapeutic alternative for cats with end-stage renal failure. Thus, the vascular anatomic requirements for the harvested kidneys are specific, to ensure surgical success.

Although it has a low prevalence in cats, the duplication of venous vessels should be differentiated from other vascular anomalies when planning surgeries and to avoid diagnostic errors.

\section{References}

ALONSO, L. S., M. ABIDU-FIGUEIREDO (2008): Double renal artery originating from aorta in dog: case report. Semina: Ciênc. Agrár. 29, 185-188 (in Portuguese).

DOI: $10.5433 / 1679-0359.2008 v 29 n 1 p 185$

ALMEIDA, B. B., U. H. BARRETO, O. M. COSTA, M. ABIDU-FIGUEIREDO (2013): Double renal artery in rabbits. Biosci. J. 29, 1294-1295.

ARTICO, M., D. LORENZINI, P. MANCINI, P. GOBBI, S. CARLOIA, V. DAVID (2004): Radiological evidence of anatomical variation of the inferior vena cava: report of two cases. Surg. Radiol. Anat. 26, 153-156.

DOI: 10.1007/s00276-003-0192-0 
A. V. Stocco et al.: Duplicity of caudal vena cava and renal veins in a feline

BASS, J. E., M. D. REDWINE, L. A. KRAMER, P. T. HUYNH, J. H. JR. HARRIS (2000): Spectrum of congenital anomalies of the inferior vena cava: Crosssectional imaging findings. Radiographics 20, 639-652.

DOI: 10.1148/radiographics.20.3.g00ma09639

BERTOLINI, G. (2010): Acquired portal collateral circulation in the dog and cat. Vet. Radiol. Ultrasound 51, 25-33.

DOI: $10.1111 /$ j.1740-8261.2009.01616.x

BUTLER, E. G. (1927): The relative role played by embrionic veins in the development of the mammalian vena cava posterior. Am. J. Anat. 39, 267-353.

DOI: 10.1002/aja.1000390207

CACERES, A. V., A. L. ZWINGENBERGER, L. R. ARONSON, W. MAI (2008): Characterization of normal feline renal vascular anatomy with dual-phase CT angiography. Vet. Radiol. Ultrasound 49, 350-356.

DOI: $10.1111 /$ j.1740-8261.2008.00378.x

CAMPOS, C. B. A., P. S. ROCHA, M. ABIDU-FIGUEIREDO (2014): Double renal vein in cats: case reports. Rev. Acad. Ciênc. Agrár. Ambient. 12, 127-131 (in Portuguese)..

DOI: 10.7213/academica.12.02.AO06

CHEN, H., S. EMURA, S. NAGASAKI, K. Y. KUBO (2012): Double inferior vena cava with interiliac vein: a case report and literature review. Okajimas Folia Anat. Jpn. 88, 147-151.

DOI: $10.2535 /$ ofaj.88.147

CORNILLIE, P., P. SIMOENS (2005): Prenatal development of the caudal vena cava in mammals: review of the different theories with special reference to the dog. Anat. Histol. Embryol. 34, 364-372.

DOI: $10.1111 /$ j.1439-0264.2005.00625.x

CORNILLIE, P., W. VAN DEN BROECK, P. SIMOENS (2008): Origin of the infrarenal part of the caudal vena cava in the pig. Anat. Histol. Embryol. 37, 387-393.

DOI: 10.1111/j.1439-0264.2008.00868.x

FAGUNDES, G. M., A. SOUZA, V. BORELLI, A. C. M. RIELLA (1990): Contribution to the study of blood drainage of the dogs kidney (Canis familiaris - Linnaeus, 1758). Biotemas. 3 , 117-127.

HUNT, G. B., C. R. BELLENGER, R. BORG, K. R. YOUMANS, P. L. C. TISDALL, R. MALIK (1998): Congenital interruption of the portal vein and caudal vena cava in dogs: six case reports and a review of the literature. Vet. Surg. 27, 203-215.

DOI: 10.1111/j.1532-950X.1998.tb00119.x

ITO, T., Y. IKEDA (2018) A case of double inferior vena cava with renal, ovarian and iliac vein variation. Anat. Sci. Int. 93, 139-143.

DOI: $10.1007 / \mathrm{s} 12565-017-0397-7$

Vet. arhiv 89 (2), 257-265, 2019 
A. V. Stocco et al.: Duplicity of caudal vena cava and renal veins in a feline

JOHNSTON, T. B (1913): Anomaly of the vena cava inferior; with a note on the relationships which help to determine the nature of anomalies of some of the abdominal systemic veins. J. Anat. Physiol. 47, 235-245.

KÖNIG, H. E., H. G. LIEBICH (2016): Veterinary Anatomy of Domestic Mammals: Textbook and Colour Atlas. $6^{\text {th }}$ ed., Artmed, Porto Alegre, p. 824 (in Portuguese).

LABORDA, J., M. GIMENO, L. DOMINGUEZ, J. GIL (1996): Anomalous caudal vena cava in the dog. Vet. Rec. 138, 20-21.

DOI: $10.1136 /$ vr.138.1.20

MAO, Y. Q., S. X. ZHU, W. ZHANG (2015): The iatrogenic injury of double vena cava due to misdiagnosis during the radical nephroureterectomy and cystectomy. World J. Surg. Oncol., 13,41 .

DOI: $10.1186 / \mathrm{s} 12957-015-0469-\mathrm{X}$

MATHEWS, R., P. A. SMITH, E. K. FISHMAN, F. F. MARSHALL (1999): Anomalies of the inferior vena cava and renal veins: embryologic and surgical considerations. Urol. 53, 873880.

DOI: $10.1016 / \mathrm{S} 0090-4295(99) 00007-2$

McCLURE, C. W. F., E. G. BUTLER (1925): The development of the vena cava inferior in man. Am. J. Anat. 35, 331-383.

DOI: 10.1002/aja.1000350302

MORITA, S., M. HIGUCHI, N. SAITO, N. MITSUHASHI (2007): Pelvic venous variations in patients with congenital inferior vena cava anomalies: classification with computed tomography. Acta Radiol. 48, 974-979.

DOI: $10.1080 / 02841850701499409$

NATSIS, K., S. APOSTOLIDIS, G. NOUSSIOS, E. PAPATHANASIOU, A. KYRIAZIDOU, V. VYZAS (2010): Duplication of the inferior vena cava: anatomy, embryology and classification proposal. Anat. Sci. Int. 85, 56-60.

DOI: $10.1007 / \mathrm{s} 12565-009-0036-\mathrm{Z}$

OLIVEIRA, F. S., G. C. GUIMARÃES (2007): Renal artery duplicity in dog. Cienc. Rural. 37, 1817-1819 (in Portuguese).

DOI: $10.1590 / \mathrm{S} 0103-84782007000600051$

PESTANA, F. M., M. S. ROZA, J. M. F. HERNANDEZ, B. X. SILVA, M. ABIDU-FIGUEIREDO (2011): Double renal artery in cat. Semina: Ciênc. Agrár. 32, 327-332 (in Portuguese).

DOI: $10.5433 / 1679-0359.2011 \mathrm{v} 32 \mathrm{n} 1 \mathrm{p} 327$

REIS, R. H. E., P. TEPE (1956): Variations in the pattern of renal vessels and their relation to the type posterior vena cava in the dog (Canis familiaris). Am. J. Anat. 99, 1-15.

DOI: 10.1002/aja.1000990102 
A. V. Stocco et al.: Duplicity of caudal vena cava and renal veins in a feline

SARLON, G., M. A. BARTOLI, C. MULLER, S. ACID, J. M. BARTOLI, S. COHEN, P. PIQUET, P. E. MAGNAN (2011): Congenital anomalies of inferior vena cava in young patients with iliac deep venous thrombosis. Ann. Vasc. Surg. 25, 265.e5-e8.

DOI: $10.1016 /$ j.avsg.2010.07.007

SCHWARZ, T., F. ROSSI, J. D. WRAY, B. ÅBLAD, M. W. BEAL, J. KINNS, G. S. SEILER, R. DENNIS, J. F. McCONNELL, M. COSTELLO (2009): Computed tomographic and magnetic resonance imaging features of canine segmental caudal vena cava aplasia. J.S.A.P. 50, 341349.

DOI: $10.1111 /$ j.1748-5827.2009.00748.x

STOCCO, A. V., N. V. STOCCO, C. A. SANTOS-SOUSA, M. ABIDU-FIGUEIREDO (2014): Triple renal vein in cat: case reports. Rev. Port. Ciênc. Vet. 109, 120-122 (in Portuguese).

STOCCO, A. V., S. C. Silva, K. S. TOLEDO, C. A. SANTOS-SOUSA, R. B. J. CARVALHO, M. ABIDU-FIGUEIREDO (2017): Double right renal vein in ocelot: case report (Leopardus pardalis). Rev. Port. Ciênc. Vet. 112, 83-86 (in Portuguese).

ŠEHIĆ, M., I. KIŠ, D. VNUK, D. Ž. HADŽIJUNUZOVIĆ ALAGIĆ, D. STANIN, H. CAPAK (2017): Three-dimensional multislice helical computed tomography in the diagnostics of vena azygos connection to the caudal vena cava in a dog - a case report. Vet. arhiv 87, 631-639.

DOI: $10.24099 /$ vet.arhiv.160623

XUE, H. G., C. Y. YANG, M. ASAKAWA, K. TANUMA, H. OZAWA (2006): Duplication of the inferior vena cava associated with other variations. Anat. Sci. Int. 82, 121-125.

DOI: 10.1111/j.1447-073X.2006.00153.x

Received: 4 November 2017

Accepted: 21 March 2019

\section{STOCCO,A. V., C.A. DOS SANTOS-SOUSA, P. SOUZA-JUNIOR, K. TOLEDO, M. ABIDU-FIGUEIREDO: Duplikacija stražnje šuplje vene i bubrežnih vena u brazilske kratkodlake mačke - prikaz slučaja. Vet. arhiv 89, 257-265, 2019. \\ SAŽETAK}

U mesojeda stražnja šuplja vena odvodi krv iz zdjelice i stražnjih udova u lijevu pretklijetku. Duplikacija stražnje šuplje vene u malih je životinja rijetko opisivana. Cilj ovoga rada jest prikazati duplikaciju stražnje šuplje vene i varijacije bubrežne vene u brazilske kratkodlake mačke, ženke dobi oko tri godine, s naglaskom na njihove moguće kliničke i kirurške značajke. Lešina je pohranjena u 10 \%-postotnom formalinu, a u krvožilni je sustav injektiran obojeni S-65 Petrolatex. Tijekom otvaranja trbušne šupljine uočene su dvostruke stražnje šuplje vene i dvije bubrežne vene u oba bubrega. Budući da se dvostruka stražnja šuplja vena rijetko nalazi u mačaka, u planiranju kirurških zahvata treba je razlikovati od drugih krvožilnih anomalija kako bi se izbjegla pogrešna dijagnoza.

Ključne riječi: brazilska kratkodlaka mačka; trbušne krvne žile; anatomske varijacije 
